\title{
Visualization of a business plan
}

\author{
N.N. Krupina ${ }^{1}$ \\ Department of Economics, Management and Public Administration of the \\ Institute of Service, Tourism and Design (branch) of the \\ North Caucasus Federal University, Pyatigorsk, Russia \\ ${ }^{1}$ ORCID: 00oo-0002-7983-845X, krupina n17@mail.ru
}

\begin{abstract}
In the investment process, business planning is viewed as the optimization of an organization's movement towards a strategic development goal in a competitive, risk, uncertainty, and dynamic market environment. The article substantiates the relevance and relevance of a broader and more thoughtful application of visual models in a business plan for successful managerial diagnostics, comprehensive comparison of alternative solutions, increasing the effectiveness of communications and securing partnerships. Visualization helps to make a potential investor not a passive observer of the business plan development process and appraiser of the proposed business idea, but an interested and active person involved in the project discussion, helping to take a fresh look at the company's strengths and weaknesses, threats and opportunities of the environment. The author discusses the information needs of groups of influence on the project, features and information and analytical potential of each element of visual content, the main sections and aspects of the project, as objects of effective visualization, and also provides specific illustrative examples. The effective effect of graphical models is explained from the standpoint of cognitive visualization ideas, when visual information is assigned the role of an important tool not only to gain knowledge, but also to increase the effectiveness of mental operations of comparison, generalization, situational analysis, analogy, choice of actions.
\end{abstract}

Keywords: business plan, visibility, visualization, visual content, tables, graphs, charts, matrices, charts, maps, signs, photographic documents, stakeholders, visual models in a business plan, break-even chart, risk chart, McKinsey matrix, Sankey chart, client asset visualization.

\section{Introduction}

Any textual expression of a new commercial idea should be understandable, interesting, fascinating and clearly showing why the interested party should implement it. The text without visual accompaniment is of little interest, as mentioned by the founder of the "graphic method» Scottish engineer-economist William Playfair in 1796: active businessmen can pay attention only to general conclusions, and with the help of graphs, information is perceived without fatigue and difficulties associated with the study of its constituent components. Visualization has become an integral part of the global communication process and is included by the UN Economic Commission for Europe in the standard model of a business process. Its opportunities in commerce and business are widely and actively discussed by world experts - Stephen Few, David McCandless, Ben Fry, Nathan Yau, Edward Tufte, Alberto Cairo, Hans Rosling, Wayne Eckerson, Gene Zelazny and others.

Due to the pronounced illustrative function, methods of activating visual thinking are widely used in the exact sciences, pedagogy, psychology, management, marketing. Business visualization is considered as a system of working with information, therefore the areas of using infographics, scribing, forcing, business modeling, techniques for processing data arrays 
(Big Data, Business Intelligence) and other techniques are actively expanding. Priorities brainstorming, training, strategic sessions, negotiations, client meetings, meetings. But a system analysis of the potential and missed opportunities of cognitive visualization in developing key sections of a business-plan is not yet sufficient, which confirms the study of visualization metaphors in business modeling, which allowed researchers to generalize its social and cognitive advantages (T. Gavrilova, 2014) [1]:

- information compression, capacity and availability of the message for perception;

- minimization of efforts to find information and ease of transferring some logical conclusions, given that the perception of the text refers to the left hemisphere (logical) activity of the brain and does not involve the cognitive resources of the right (figurative) hemisphere, i.e. not effective enough;

- increase in the efficiency of perception of data when switching attention, because the release of a large amount of memory frees up an additional amount of a person's working memory and thereby simplifies the memorization and retention of details in consciousness;

- the ability to integrate different points of view, contributing to mutual understanding and facilitating the interaction of people in a team;

- the formation of a sense of involvement in teamwork, as well as the development of creative potential and the strengthening of partnerships.

The developer of an investment project should pay attention to key issues, arouse interest in cooperation, justify the benefits and effects even in the presence of risks and competition. The clarity of arguments, convincing facts, calculation results and comparative estimates, figurative clarity of information and evidence of the reality of the idea are important.

This allows us to identify the specifics of business processes that cognitive visualization should take into account:

- the focus of the business-plan on attracting investments, which implies not only objectivity, accuracy of forecasts and thorough verification of information, but the mandatory presentation of alternative options for capital allocation;

- dynamism, risk, uncertainty of the environment, complicating its forecasting;

- a lot of direct and feedback, factors separated in space and time of cash flows, the non-linear nature of the processes.

The article discusses potential graphic tools and the most popular classical visual models, provides illustrative examples of visualization in solving practical problems during business-planning.

\section{Visual content}

The generally accepted symbolic representation (visual content) help to focus attention in the text of the project on the most important organizational, commercial, marketing, merchandising experts, trade and procurement, financial and economic, analytical, planning and forecasting, regulatory and foreign trade aspects of the business. Charts, graphs, tables, maps, and other cognitive-visual tools become a source of new forms of awareness of information and the basis of decision-making systems, which corresponds to such principles of the human brain as «multitasking» (Kozubovsky VM, 2008) [2] and «serendipity » (Bolter JD, 2014) [3].

Visualization allows a trained user to optimize work with an array of «routine» specific information through the use of ready-made mental structures that reduce cognitive effort and time, simplifies the process of assessing the context (Zakharova A.A., 2016) [4]. It is important to note that only a competent user is in a state of «directed waiting» when he is already aware of possible scenarios for the development of business activity, and an informative event is a formalized transition from one state to another.

Firstly, homogeneous objects are grouped and systematized in the tables, which makes it possible to identify the composition, sizes, structure, dynamics of processes, trends (growth, fall, seasonal fluctuations). The simplicity of compilation, consistency, reasonable- 
ness, compactness, the ability to quickly correct information, the convenience of computer processing and archiving make them a universal visualization technique. For example, a company manufacturing office furniture, in terms of marketing in the format of a combination table, presents a forecast of sales by market segments, regions and assortment groups (table 1). The reader immediately focuses on the overall results - the revitalization of business activity, sales growth, the region with high demand (Central region) and the general favorable environment for the implementation of a new commercial idea.

Secondly, the graphs, which also help to overcome the formlessness and fragmentation of digital data, to give them a more strict order and clarity, explain the patterns of development of the business process in the long term. The data array receives new knowledge, causeeffect relationships between market processes are indicated, and existing inaccuracies and errors in the calculations are revealed.

Thirdly, diverse charts hold and focus on the content of the project when comparing alternative solutions to problems or analyzing individual aspects of the business. The influence of individual characteristics of perception in interpreting an event becomes minimal, only changes are recorded, and reading a visual message does not change the types of thought processes (Madigan S., 1974) [5].

Table 1. Dynamics of sales of the company (million rubles)

\begin{tabular}{|c|c|c|c|c|c|c|c|c|}
\hline \multirow[t]{3}{*}{ View production } & \multirow{3}{*}{$\begin{array}{l}\text { Volume } \\
\text { of sales }\end{array}$} & \multirow{3}{*}{$\begin{array}{c}\text { Share, } \\
\%\end{array}$} & \multicolumn{6}{|c|}{ Including sales regions and years } \\
\hline & & & \multicolumn{3}{|c|}{ North-Western } & \multicolumn{3}{|c|}{ Central } \\
\hline & & & 1 & 2 & 3 & 1 & 2 & 3 \\
\hline - school desk & 100,0 & 16,5 & 2,5 & 5,5 & 10,0 & 20,0 & 25,0 & 37,0 \\
\hline - dining table & 49,4 & 8,2 & 2,4 & 7,0 & 10,0 & 6,0 & 10,0 & 14,0 \\
\hline Total & 149,4 & 24,7 & 4,9 & 12,5 & 20,0 & 26,0 & 35,0 & 51,0 \\
\hline closet & 36.6 & 6,0 & 1,6 & 2,0 & 3,0 & 8,0 & 10,0 & 12,0 \\
\hline mini-closet & 50,0 & 8,3 & 2,0 & 2,5 & 3,5 & 12,0 & 15,0 & 15,0 \\
\hline Total & 86,6 & 14,3 & 3,6 & 4,5 & 6,5 & 20,0 & 25,0 & 27,0 \\
\hline office shelving & 97,0 & 16,0 & 3,0 & 4,0 & 10,0 & 15,0 & 25,0 & 40,0 \\
\hline cabinet rack & 100,0 & 16,6 & 5,0 & 10,0 & 15,0 & 15,0 & 20,0 & 35,0 \\
\hline Total & 197,0 & 32,6 & 8,0 & 14,0 & 25,0 & 30,0 & 45,0 & 75,0 \\
\hline 1 bed side table & 71,0 & 11,8 & 1,0 & 3,0 & 6,0 & 11,0 & 20,0 & 30,0 \\
\hline 2 bed side table & 100,0 & 16,6 & 5,0 & 8,0 & 10,0 & 18,0 & 22,0 & 37,0 \\
\hline Total & 171,0 & 28,4 & 6,0 & 11,0 & 16,0 & 29,0 & 42,0 & 67,0 \\
\hline TOTAL & 604,0 & 100 & 22,5 & 42,0 & 67,5 & 105,0 & 147,0 & 220,0 \\
\hline
\end{tabular}

The diagrams are used very thoughtfully: the comparison can be component-wise, positional, temporal, frequency, correlation. So, a diagram of the form «entity - relationship» (ER) is used to describe the nature, structure and attributes of products, relationships between the results of business processes (Kuznetsov SD, 2005) [6].

During the implementation of the project, deviations from the intended indicators may occur. These can be an increase in the production time of an order that happens due to marriage, equipment downtime a decrease in sales. Therefore, using comparison charts and structural diagrams in the text of the business-plan, you can illustrate and evaluate the permissible deviations by key indicators. The former reflect the correlation of a certain characteristic of the process under study and give an idea of its uniformity or unevenness, general dynamics and trends, the latter reflect the composition and proportion of specific elements in the total population.

It is unacceptably rare to use a balance sheet that allows you to formalize the project budget: the height of the column corresponds to the value of the asset (liability), and the inner rectangles correspond to the value of their component elements. By presenting charts be- 
fore and after the project, you can clearly demonstrate the benefits of the business, the distribution of key resources and income.

In our opinion, the name charts are very effective in representing the market capacity, production capacity potential, level of innovation of the selected technology, product range, competitive advantages, and the amount of future costs is also underestimated. Varzar signs can be effective for simultaneously displaying three commercial indicators, one of which is a product of the other two. The example are sales (revenue) that take into account the price and quantity of the product. Having nearby signs relating to different objects, alternative projects or processes implemented by competitors, a factor analysis of the event can be carried out. Pareto chart - a downward bar chart in which the bars indicate the causes of the problem, and the height indicates the frequency of their occurrence. A variant of the diagram based on the results of activity is useful in identifying the main problem associated with either product quality (defects, failures, errors); or with cost (volume of losses, costs); or with safety (accidents, accidents, injuries, operational errors).

A variation of the diagram by reason distributes the causes of the problems in order of importance. The Lorentz curve is a graphical representation of the concentration level of a phenomenon using axes with the same scale percentage scale from o to 100, where successively accumulated (cumulative) results of changes in characteristics (for example, income distribution) are recorded. A straight line at an angle of 450 indicates complete distribution uniformity: the farther the actual line is from it, the less uniform the distribution.

Fourth, matrices, as a tool for situational analysis, allow you to present alternatives to business development and position the current state of the company under the influence of market forces (Loginov G.O., 2004) [7]. These are peculiar map tables with a small (4 - 9) number of rows and columns forming a segment (quadrant) at the intersection. One vector indicates the characteristics of the functions and properties of the object, the other - the level of their manifestation («strong», «medium», «weak»). The position in the quadrant of the matrix characterizes the specific proportions and combination of the two main aggregated characteristics of the competitive environment. The developer of a business idea has the opportunity with the help of matrices to attract attention and comprehend the vision of strategic behavior in the process of implementing a business-plan.

The appropriateness of using matrices is explained by the objectivity of certain organizational principles: a) the company's orientation to long-term and continuous profitable activity, when the development of a strategy and methods for its implementation is mandatory, and b) all commercial operations generate predicted and managed cash flows, which implies their modeling, including number and matrix. A classic example is the Boston matrix, which displays the growth rate of demand in the market segment and the company's position relative to the competition in the distribution of cash flows generated by specific product groups.

Fifth, the schemes are the simplest and most clear informal means of enhancing abstract thinking, that focus on the main aspects of a business plan and lead to an understanding of the logic of an event or patterns of a commercial process, as well as describe process regulations (technologies, organizational structures, goods and cash flows ) or causal relationships in them. According to the theory of perception of Nysser U., schemes guide the cognitive process, give a detailed image of the designed entrepreneurial activity and at the same time provide a favorable psychological climate and positive emotions during the discussion. The experts of the British Deming Association define the ability to describe processes using flowcharts or "process cards» as an important managerial competency that ensures the successful transformation of production resources and the achievement of the desired measurable results. The scheme gives an idea of the composition of the most important elements, the order of the actions, the essence of the interaction of the performers, the distribution of areas of responsibility, and also helps to identify potential bottlenecks and areas for improving the business process. Formalization of the business process in the form of a scheme contributes to a clear understanding of how the company works; what are the standards of the processes, 
how is the business managed and the interaction of units is achieved in order to achieve overall performance.

There are block diagrams, text schemes, text block diagrams, table diagrams, diagrams-figures, circle diagrams, diagrams-tables-figures-circles, spider schemes. This diversity is due to significant differences in nature, features and properties of knowledge of various subject areas of commerce. So, tree diagrams, or graphs, demonstrate a hierarchy of a data set in which elements are children in relation to each other. Universal structural-logical schemes create a special visualization in the illustration of successive relationships based on associations characteristic of long-term human memory. The Ishikawa scheme («fish skeleton») is known for demonstrating: a) a chain of interrelated causes of the problem; b) analysis and structuring of processes in the enterprise; c) assessing the relationship of cause and effect relationships; d) the level of lean production. In the banking sector, the use of the Ishikawa method is recommended in the BABOK® Guide [8].

Sixth, the map displays a specific event in relation to space (region, territory) and contains signs, geometric shapes, background coloring, hatching. These can be locations of production shops, territories of market promotion and sales of a product, segments of customers or debtors of a company, regions of locations of suppliers, etc. To argue the choice of the best technology variant or form of sales, alternative comparison indicators are used: objects are compared in terms of productivity, sales volume, investment payback periods, profitability, etc. Cartograms and card diagrams make it possible to visually reflect more complex production and business relations and relationships.

Seventh, signs and photo documents. Signs are a specific method of conditionally graphic visualization, a kind of "identification mark", a pointer, a label that helps to express certain concepts and represent ideas, phenomena, events in the process of exchanging information. Signs do not give ready conclusions, formulations. However, they develop abstract thinking and help to focus on the desired fragment of the text and lead to the understanding of one or another pattern, fully reflect the key tasks, the benefits, benefits and amenities, as well as create a brand model. Photo documents are used to materialize a commercial idea from the standpoint of real or subconscious needs and desires of partners. They document the ongoing processes and events, manufacturing techniques or active sales, operating techniques, and functions performed. Such displays inspire confidence not only among partners, but also among all parties interested in the project.

Thus, in business planning, visualization is achieved by coding techniques and "works" on the intellectual and emotional levels as an aesthetic and readable format that is transformed by the brain into a metal image using the following cognitive operations (Langacker R., 2000) [9]:

- specification (level of generalization and schematization of forecast data);

- focusing (emphasis on key issues and the task of the business process);

- highlighting (detailing of identified problems and tasks);

- perspectivization (the formulation of a point of view, i.e., the implementation of a cognitive device for understanding information).

According to the ideas of M. McLuhan, an expert in the field of communication, the sensual attitudes of modern people are mostly visual in nature, much more gravitate to wordless perception and image. Other researchers (Pirolli P., 1995) [10] noted a natural desire of a person to reduce labor costs when searching and interpreting an array of information. However, one should not exclude the danger of a negative cognitive perception of «redundant graphics» or too simplified "pictures» due to the developer's lack of professionalism, inaccurate information, limited technical capabilities or unsuccessful templates, as well as an insufficient level of financial, economic or managerial training for the user.

The fundamental point in motivation for a positive perception of business information and the formation of balanced strategic decisions is the coordination of interests of participants (stakeholders) in future business processes. Agreeing with the opinion that an individual competes or cooperates in the market, has emotionality, accumulates experience and en- 
riches his mental models, based on which he makes decisions, but never has complete information (Lychkina N.N., 2016) [11], we made an attempt to detail the information needs of participants in the business process (table 2).

Table 2. Information needs of project stakeholders

\begin{tabular}{|c|c|c|}
\hline Stakeholders & Information Needs & Aspects to Visualize \\
\hline $\begin{array}{l}\text { 1. Leadershipand } \\
\text { shareholders }\end{array}$ & $\begin{array}{l}\text { Legality. Business value, image, } \\
\text { investment attractiveness. Quality and } \\
\text { return on labor. Payback, profitability, } \\
\text { return on investment. Loyalty of } \\
\text { consumers and staff. }\end{array}$ & $\begin{array}{l}\text { Profitability of the project. The } \\
\text { payback period of the investment. } \\
\text { The novelty level of the project. } \\
\text { Competitive advantages. Break- } \\
\text { even model. }\end{array}$ \\
\hline $\begin{array}{l}\text { 2. Lenders and } \\
\text { Investors }\end{array}$ & $\begin{array}{l}\text { Все вышесказанное, а также динамика } \\
\text { рынка (концентрация и рост спроса, } \\
\text { реальность его удовлетворения, риски), } \\
\text { кредитоспособность, репутация }\end{array}$ & $\begin{array}{l}\text { Sources of investment, payback } \\
\text { period Completeness of the } \\
\text { project risk assessment. } \\
\text { Reputation, Social Responsibility }\end{array}$ \\
\hline $\begin{array}{l}\text { 3. Employees and } \\
\text { union } \\
\text { representatives }\end{array}$ & $\begin{array}{l}\text { Social policies, change programs and } \\
\text { business restructuring plans. Training } \\
\text { programs, exchange of experience, } \\
\text { internships. Salary. }\end{array}$ & $\begin{array}{l}\text { Strategy, career opportunities } \\
\text { and competency development, } \\
\text { opened by new business plans }\end{array}$ \\
\hline $\begin{array}{l}\text { 4. Government } \\
\text { bodies }\end{array}$ & $\begin{array}{l}\text { Law enforcement, tax discipline, } \\
\text { employment support. Social } \\
\text { responsibility. Foreign economic activity. }\end{array}$ & $\begin{array}{l}\text { The tax potential of the project } \\
\text { and its budgetary effects. New } \\
\text { workplaces. Environmental } \\
\text { friendliness. }\end{array}$ \\
\hline $\begin{array}{l}\text { 5. Business } \\
\text { partmers and } \\
\text { intermediaries }\end{array}$ & $\begin{array}{l}\text { Fulfillment of obligations, reputation. } \\
\text { Prospects for the growth of cooperation - } \\
\text { ethical standards }\end{array}$ & $\begin{array}{l}\text { Partnership risk. Common risks. } \\
\text { Receivables }\end{array}$ \\
\hline 6. Consumers & $\begin{array}{l}\text { The quality and availability of the product } \\
\text { or service. Safety and certification. } \\
\text { Advertising. Marketing tools }\end{array}$ & $\begin{array}{l}\text { Benefits from the purchase of } \\
\text { goods. Flexible price. Discounts, } \\
\text { promotions, bonuses, benefits }\end{array}$ \\
\hline 7. Competitors & $\begin{array}{l}\text { Price dumping risk. Commodity and } \\
\text { marketing policies. Competitive } \\
\text { advantages. Market share }\end{array}$ & $\begin{array}{l}\text { Comparative evaluation of } \\
\text { results and market positions }\end{array}$ \\
\hline $\begin{array}{l}\text { 8. Local } \\
\text { community }\end{array}$ & $\begin{array}{l}\text { Direct and indirect benefits, damage, } \\
\text { problems of the company in the } \\
\text { municipality. Support for local } \\
\text { infrastructure. Sponsorship. }\end{array}$ & $\begin{array}{l}\text { Charity. Contribution to local } \\
\text { community development and } \\
\text { concrete results. Public } \\
\text { Partnership Ideas }\end{array}$ \\
\hline $\begin{array}{l}\text { 9. Nonprofit } \\
\text { Organizations }\end{array}$ & $\begin{array}{l}\text { The contribution of the organization to } \\
\text { sustainable social development and the } \\
\text { protection of the interests of public } \\
\text { groups. }\end{array}$ & $\begin{array}{l}\text { Global interests. } \\
\text { Tour programs for company } \\
\text { services. Advertising }\end{array}$ \\
\hline 10. Media & $\begin{array}{l}\text { Openness, readiness for contacts and } \\
\text { partnerships, the possibility of criticism }\end{array}$ & $\begin{array}{l}\text { Public Benefits, Results, and } \\
\text { Effects }\end{array}$ \\
\hline $\begin{array}{l}\text { 11. International } \\
\text { organizations }\end{array}$ & $\begin{array}{l}\text { Lean manufacturing practice. Prospects } \\
\text { for sustainable development. } \\
\text { Contractability, legality. }\end{array}$ & $\begin{array}{l}\text { Results for society and the } \\
\text { world. Integration into the global } \\
\text { space. }\end{array}$ \\
\hline
\end{tabular}

The information needs of the parties will allow for more thoughtful selection of appropriate cognitive-visual tools for structuring and presenting an array of information, thereby identifying implicit knowledge and consciously affect the quality of decisions. Visualization 
minimizes cognitive efforts, allows us to discuss promising methods of visualization in understanding the economic content and functions of specific business processes (table 3).

Each type of visibility, to one degree or another, corresponds to certain business areas, graphic techniques, and classic business analytics models. The user easily moves from the visual image of the problem being solved, to the mental image-answer, as a result of using his own knowledge to interpret known patterns. The separation of visualization types creates the prerequisites for highlighting and concretizing possible promising methods of cognitive visualization, taking into account the level of user understanding and the essence of the problem being solved. This explains, for example, the use of 50 matrices of different directions in management and marketing, which allows us to point out their advantages for planning: multifunctionality (information, comparison, control, diagnostics); targeting (attachment to a production or market situation); fixing of alternative options taking into account the prevalence of positive or negative conditions.

Numerous psychological and pedagogical studies, in particular the works of academician A. Verbitsky [12], it was proved that visualization is much wider than simple visual perception, it organizes analytical and cognitive activities at the stage of perceiving and processing information, and then it successively affects the depth of understanding of models and provides meaningful new knowledge. Let us make an assumption that management planning, as an abstract thought process, is less focused on visualization, and suggests its maximum combination with cognitive and cognitive activity, leading to critical thinking, rethinking and subsequent transformation of specific data (Syrina T.A., 2016) [13], possibly through the construction of «associative images» (Manko, 2009) [14]. This assumption was used by us to search for effective cognitive techniques for arguing the provisions given in the main sections of the business plan.

\section{Key aspects of visualization in a business-plan (illus- trative examples)}

A business-plan is characterized by goal setting, duration, limited resources, coordinated interaction of responsibility centers and a set of indicators (technical, economic, financial, industrial, social). We assume that these characteristics objectively reflect the existing requirements for the selected visual content. The choice of graphic models and images is of fundamental importance, because only well-chosen expressive means in the conditions of objective limited short-term memory (due to the supplanting effect of subsequent characters) provide his motivation for constructive dialogue and focus on the desired result. The business-plan should clearly define the sections and detail the text in them, highlight the aspects of greatest interest for visualization and consider the sequence of presentation of graphic models and illustrations. An analysis of the literature, recommendations of various financial institutions and business planning practices allows us to determine the fundamental sections of the document as objects of mandatory and effective cognitive visualization (Fig. 1).

We describe the key aspects of these sections:

1. Production plan: - industrial site infrastructure, past experience in implementing investment projects; power input schedule; critical volume of production; dynamics of indicators of the state of fixed assets and staffing. 
Table 3. Visual methods in the presentation of the project (compiled by the author on the basis of visual classification [5])

\begin{tabular}{|c|c|c|c|}
\hline Type of visibility & Business line & Receptions renderings & Classic models \\
\hline $\begin{array}{l}\text { OPERATIONAL } \\
\text { formation of general ideas, } \\
\text { knowledge; informing, comparing, } \\
\text { illustrating, etc. }\end{array}$ & $\begin{array}{l}\text { - description of the current state and changes } \\
\text { - business alternatives comparison } \\
\text { - quality control and process monitoring } \\
\text { - forecasting and sales planning } \\
\text { - workload time planning } \\
\text { - organizational planning }\end{array}$ & $\begin{array}{l}\text { - tables and drawings } \\
\text { - graphs and charts } \\
\text { - schemes, flowcharts } \\
\text { - maps and maps-scheme } \\
\text { - spark } \\
\text { - photo documents }\end{array}$ & $\begin{array}{l}\text { - balance sheet } \\
\text { - forms of statistical and } \\
\text { financial reporting } \\
\text { - Pareto chart } \\
\text { - stock summaries } \\
\text { - «on-line» monitoring }\end{array}$ \\
\hline $\begin{array}{l}\text { STRUCTURAL } \\
\text { analysis and assessment of the } \\
\text { structure, designation of causal } \\
\text { relationships }\end{array}$ & $\begin{array}{l}\text { - description and presentation of the structure } \\
\text { - factor analysis of the business process } \\
\text { - mapping links and sequences } \\
\text { - bankruptcy self-diagnosis }\end{array}$ & $\begin{array}{l}\text { - network graphics } \\
\text { - strip patterns } \\
\text { - tree and graphs } \\
\text { - mental cards }\end{array}$ & $\begin{array}{l}\text { - Gantt chart } \\
\text { - Boston matrix } \\
\text { - McKinsey matrix } \\
\text { - ABC-chart }\end{array}$ \\
\hline $\begin{array}{c}\text { BACKGROUND } \\
\text { creating an intensity background } \\
\text { around the graphic }\end{array}$ & $\begin{array}{l}\text { - investment design } \\
\text { - corporate trainings, training } \\
\text { - investment portfolio management } \\
\text { - public relations and advertising }\end{array}$ & $\begin{array}{l}\text { - illustrations and matrices } \\
\text { - curly charts } \\
\text { - color schemes and drawings } \\
\text { - strip patterns }\end{array}$ & $\begin{array}{l}\text { - situational maps } \\
\text { - density plots } \\
\text { - radial diagrams } \\
\text { - complex diagrams }\end{array}$ \\
\hline $\begin{array}{l}\text { CONTINUITY } \\
\text { associative relationships within the } \\
\text { graphic image }\end{array}$ & $\begin{array}{l}\text { - scenario modeling } \\
\text { - situational analysis, identification of trends } \\
\text { - forecasting and planning } \\
\text { - characteristics of the enterprise and product }\end{array}$ & $\begin{array}{l}\text { - network diagrams, schemes } \\
\text { - logistic schemes } \\
\text { - strip patterns } \\
\text { - tree of decisions }\end{array}$ & $\begin{array}{l}\text { - breakeven chart } \\
\text { - tolerance curves } \\
\text { - graphs in polar and spherical } \\
\text { coordinates }\end{array}$ \\
\hline $\begin{array}{c}\text { FORMALIZED } \\
\text { placement structure, highlighting } \\
\text { key aspects, external design }\end{array}$ & $\begin{array}{l}\text { - accounting and reporting } \\
\text { - investment design, business planning, business } \\
\text { modeling } \\
\text { - control and monitoring }\end{array}$ & $\begin{array}{l}\text { - tables and graphs } \\
\text { - Sankey chart } \\
\text { - histograms } \\
\text { - radial diagrams }\end{array}$ & $\begin{array}{l}\text { - areal diagrams } \\
\text { - ring card } \\
\text { - Venn/Euler diagram } \\
\text { - thermal diagram }\end{array}$ \\
\hline $\begin{array}{l}\text { DISTRIBUTIVE } \\
\text { increasing the level of accessibility } \\
\text { of perception, understanding, } \\
\text { analysis, highlighting the main } \\
\text { thing, assimilation, communication }\end{array}$ & $\begin{array}{l}\text { - branding, development of trademarks and } \\
\text { trademarks, marking, advertising } \\
\text { - professional advice } \\
\text { - management analysis and deviation analysis }\end{array}$ & $\begin{array}{l}\text { - fractal and vector graphics } \\
\text { - architectural plan } \\
\text { - areal charts } \\
\text { - tag clouds }\end{array}$ & $\begin{array}{l}\text { - Boston matrix } \\
\text { - curly charts } \\
\text { - quality profile } \\
\text { - Maslow Pyramid } \\
\text { - Ishikawa chart }\end{array}$ \\
\hline
\end{tabular}



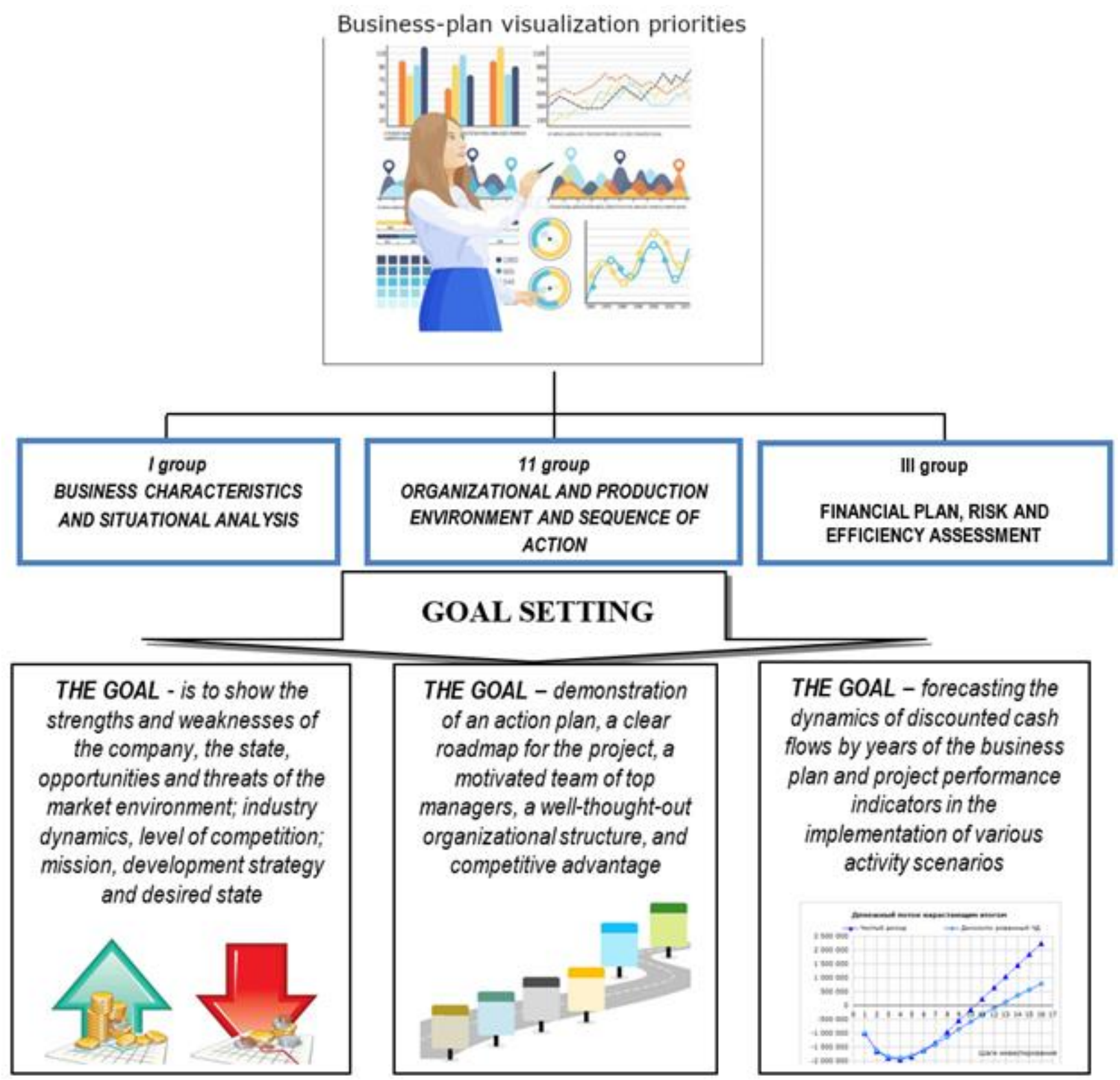

THE GOAL - forecasting the dynamics of discounted cash flows by years of the business plan and project performance indicators in the implementation of various activity scenarios

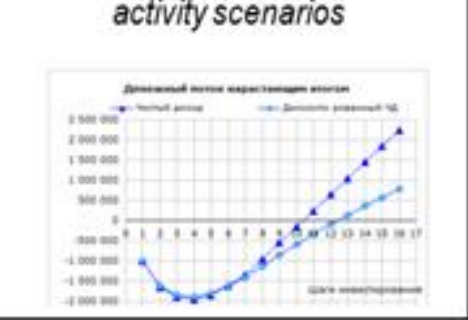

Fig. 1. Sections of the business-plan as objects of mandatory visualization

2. Characteristics of the product, industry, enterprise: organizational structure and top management; the most important characteristics and product samples; compliance with standardization and certification requirements; life cycle phase; business environment dynamics; substitute products and related products and services, competitive advantages.

3. Marketing plan: market capacity and growth; price elasticity of supply and demand; market segmentation, market share of firms; non-price factors affecting supply and demand; distribution channels; upper and lower price limits; marketing mix and competitive advantage of the product introduced to the market.

4. Financial plan: cash flow balance (with a return on investment); structure of investment sources (with mixed financing); repayment schedule for financial obligations; payback period of investments; performance indicators.

5. Risk assessment: project sensitivity analysis schedule; risk curves or risk maps for key types of project risks.

Let's look at a few examples.

Example 1. Break-even chart. This is a simplified visual model of the effectiveness of commercial activity, when an organization that does not reach and does not exceed the breakeven point is not effective. The break-even chart is presented in the production section 
of the business plan to justify the volume of output and sales of products (services) in the short term and subsequent planning of sales prices and calculation of the payback period of investments. The model successfully demonstrates the "project security» for the investor and the entrepreneur's ability to repay the loan in a timely manner with a positive market environment.

She shows:

- for the enterprise - the smallest volume of output at which costs are fully offset by revenue, and subsequent production makes a profit;

- for a service company - the volume of services (works) rendered, which allows to fully cover existing losses and receive income from subsequent activities;

- for a shopping facility - the smallest value of goods turnover required to cover own expenses;

- for a portfolio investor - the length of time during which the profit received from the transaction (investment in securities) covers the costs of the transaction, but in the subsequent period, the preservation of assets will already bring legal income.

The uncertainty of the competitive environment imposes restrictions on the scale of the business, therefore, when planning, it is necessary to clearly define the limits of capacity (cost), which will allow the investor to make sure that the rational use of limited resources and the concentration of intellectual efforts to ensure its most important requirements. Suppose that an entrepreneur chooses a site for the construction of a workshop for the production of products. The location determines the costs (primarily transport and energy), so the preferred option is the organization of the process with a smaller break-even. Comparison of alternative sites is carried out under comparable conditions, i.e. with the same volume of production. Two curves are built in the graph field - the revenue line and the total cost line, and the point of their intersection corresponds to the critical volume of production (Fig. 2). A profit zone is fixed to the right of the sign point, and a loss zone to the left, which facilitates the choice of the preferred option. In our example, this is the second site: annual losses are covered by the smallest output of 430 tons instead of 700 tons.

A decrease in the break-even point means a quick payback of the project and lower investment risks, and a noticeable expansion of the profit zone with equal capacity (1200 tons/year) means a large amount of income and an increased margin of financial strength. There is also a high probability that the size of the allowable loss of revenue while reducing demand and reducing the level of capacity utilization by 15-20\% (up to 950-1000 tons/year) will not lead to the loss of all income. This important conclusion can easily be made on the basis of a visual representation of the position of the profit zone on the chart. Another significant point concerns the management of production costs - in the same conditions for the organization of production, the use of effective control and the use of lean manufacturing technology at the second site can provide greater resource savings and greater additional income.

Break-even is a significant signal about the sufficiency of the project for specific stakeholders. For ordinary shareholders, this is the gross profit zone, which shows that the project ensures sustainable reproduction, timely payment of dividends and predictability of their size, and for preferred shareholders, this is the zone of minimal estimated profit, which demonstrates that the project guarantees dividends even in an inefficient mode. For lenders and borrowers, the model fixes the limit of the project's ability to provide financial obligations at the expense of the remaining own property, and for supervisory and controlling authorities - the conditions for achieving design capacity, which means ensuring employment, stability of tax revenues to budgets of all levels, saturation of the consumer market with quality products 

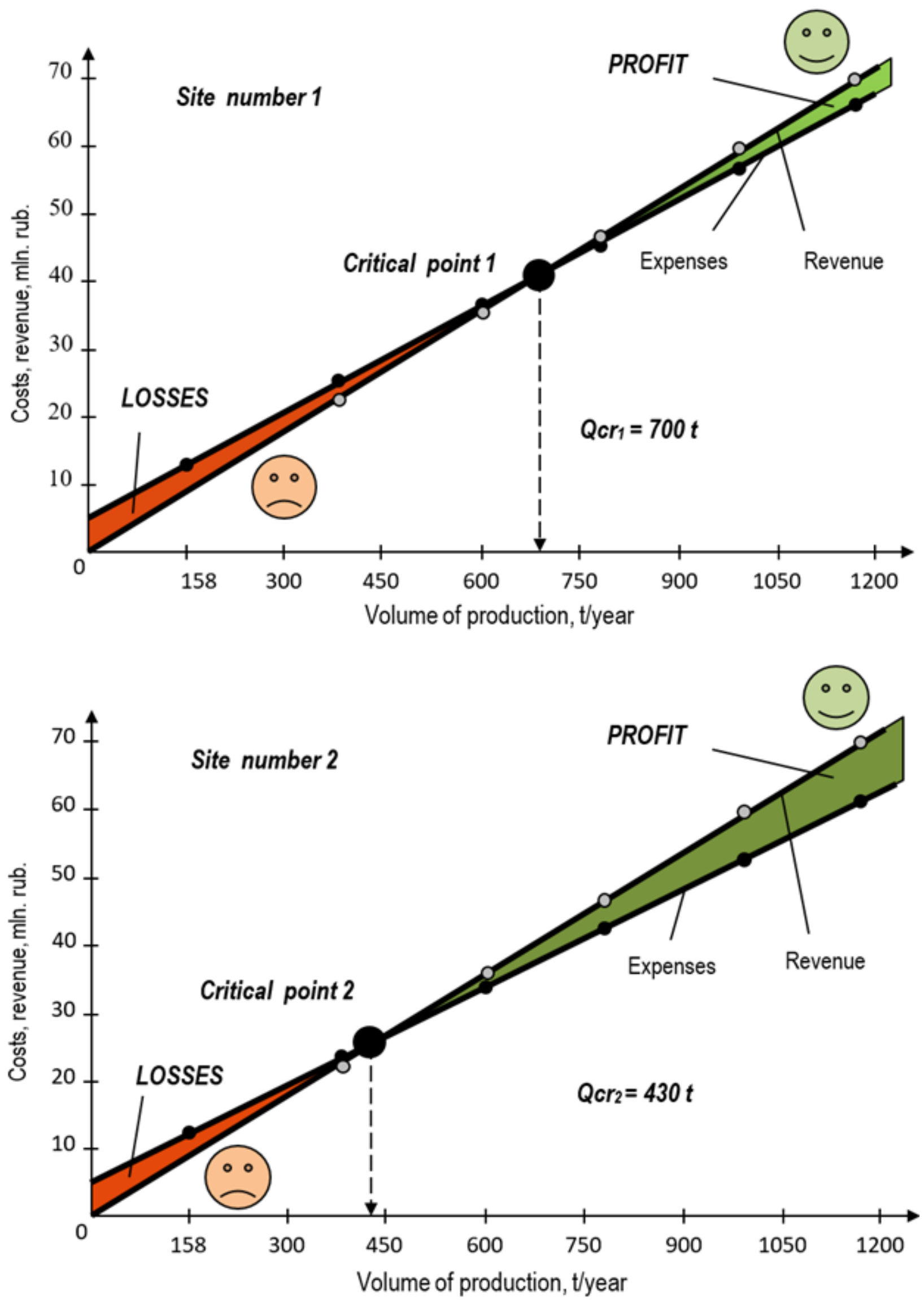

Fig. 2. Comparison of sites for the implementation of a business-plan at the breakeven point. 
Example 2. The McKinsey Matrix. One side of the matrix captures the competitive position of a strategic business unit, its relative advantage. The other defines the attractiveness of the industry in which this business unit operates. The matrix has a dimension of $3 \times 3$ (9 quadrants), which allows reflecting three gradation levels of the degree of manifestation of key characteristics - high (strong), medium, low (weak). Business units are reflected in the quadrants of the matrix in the form of circles with centers at the intersection of the corresponding indicator values. The size of the circle is proportional to the volume of sales in this market segment. Three areas are formed - winners (leaders) of the market, losers and stable agents (diagonal).

Suppose that in a highly competitive regional market for information services, the chief manager of an Internet cafe analyzes the competitive positions of the following basic services: 1 - connecting personal devices to a power outlet (in comfortable conditions); 2 - Internet access (several Wi-Fi points); 3 - Skype communication; 4 - network games; 5 - preservation, duplication, printing of information; 6 - use of software packages; 7 - sale of coffee, tea and chilled drinks. Consumers - schoolchildren, students, entrepreneurs, managers, teachers, retirees. To characterize the services, their quality, innovativeness, market share, unit costs and staff competencies were chosen, to characterize the attractiveness of the industry, the size and growth rate of the market (demand), differentiation of services, consumer value for the company, level of competition and the average industry profit margin. The McKinsey matrix is shown in Fig. 3. She effectively describes the situation, allowing us to state that all services are profitable, falling into the zone of attractive market segments. Three products (Internet access, network games, drinks selling) fall into the leader area, other services are viable and occupy stable middle positions, except for one (No. 3 - Skype communication). In general, the competitive position of Internet cafes can be called good, and managers should maintain their positions, make selective investments in the development of the «connect personal devices to the outlet» service, for example, increasing the comfort level of seats and the service culture. The service «communication on Skype» is the most «bottleneck» of the company, its further improvement is required. Individual segment colors and circle sizes create a harmonious and harmonious design of the model, and its analytical potential can be enhanced by the development of interrelated indicators that comprehensively characterize the new business process from the standpoint of management efficiency, level of frugality, scientific organization of labor, efficiency of working capital management, creditworthiness, and the effectiveness applied systems of marketing, market promotion and support of products, risk assessment of unclaimed services.

Example 3. Sankey diagram. In the Google Analytics system, flowcharts are widely represented for describing business processes. In particular, the Sankey diagram, those main idea is to visually divide the whole into its component parts. This specific chart forms the clarity, accuracy and speed of solving the analytical problem, and also enhances the visual fixation and readability of the graph. It has been shown that in landscape planning, the combination of categorical maps and Sankey diagrams reduces the complexity of the analysis, increases clarity in the presentation of the initial data and forecast scenarios, and activates communication between researchers and practitioners (Cuba N. 2015) [15]. It is noted that the effectiveness of perception is achieved by taking into account the context and semantic relationships between numbers and graphic images, color coding, changing the composition and shape of flows (V.V. Laptev, 2017) [16]. The Sankey chart can find its place in the business plan when assessing possible losses of raw materials or cash resources distributed between risk events to support the conclusion about the feasibility of the investor's main interest - guaranteeing a refund and interest on time. 


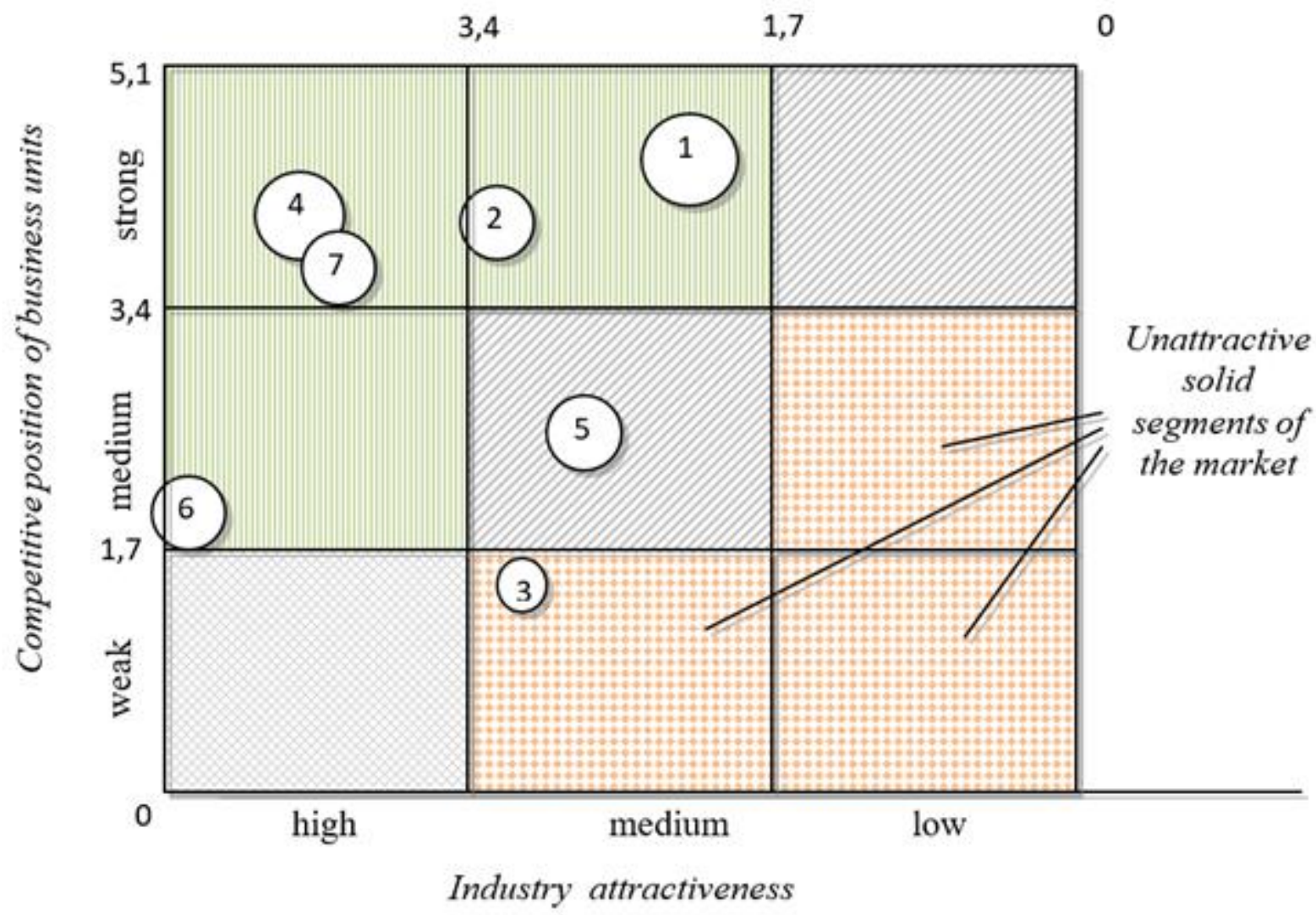

Fig. 3. The McKinsey Matrix for Internet cafes

Suppose that the size of the insurance reserve and the distribution of credit risk associated with natural, human, inflation, and bank risks are justified (Fig. 4). The diagram shows the process of generating cash flows from the totality of possible risks, taking into account their probability in all functional processes (integrate flows into a network); identify the dominant flows and the required volume of guarantees (demonstration of security of obligations); detect weaknesses of the idea and evaluate the effectiveness of the measures taken. By the width of the segment, one can judge the probability of risk or the size of the losses, the sequence and direction of flows are in the form of an arrow, and the flow intensity for a certain period is the size of the arrow.

Example 4. Project risks. Traditionally, the bank's credit department specialists expect to see a risk curve or risk map in the business-plan. However, for short-term local projects of small business, simpler methods of graphic illustration that take into account the psychophysiological characteristics of the perception of elements grouped in a certain way, the so-called gestalt principles, may be interesting [17]. Signs located close to each other (principle of proximity), similar in size, color scheme or shape (principle of similarity), close in time and space (adjacency) are well perceived. At a conscious level, a more accurate perception of the length and two-dimensional arrangement of signs, their orderliness, the importance of saturation, brightness, contrast of color perception, as well as a combination of numbers and words in the image (Few S., 2006) [18] were noted. This allows us to assume that a figurative symbolic representation of the probability of risks in a business plan may be as successful in initiating adequate conclusions and actions as a bar chart. 


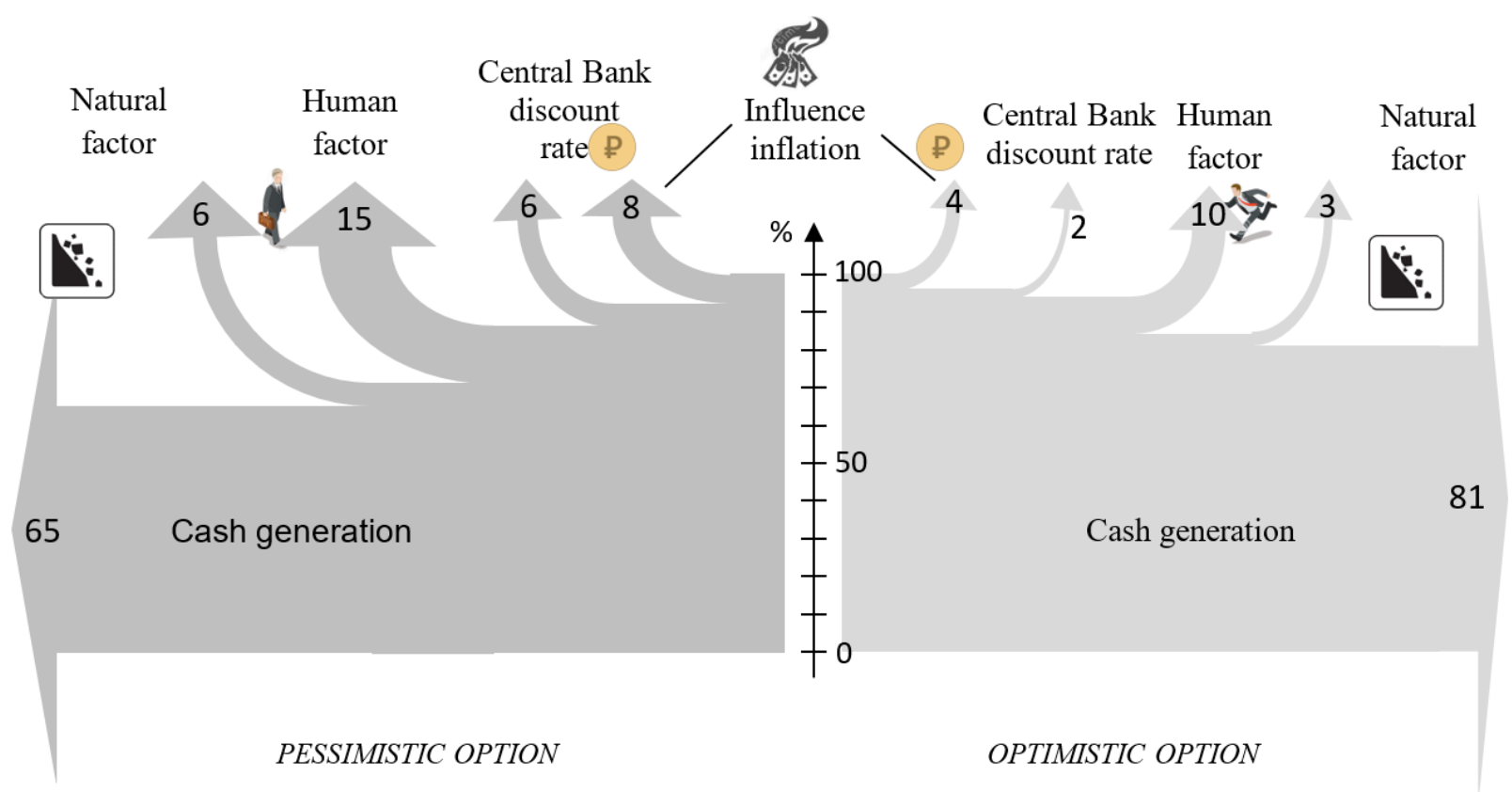

Fig. 4. Sankey chart - project credit risk allocation

Suppose a successful company plans to create a new production line. Experts identified five types of risk: errors in the construction of logistics schemes for goods flows; lack of demand for products; insufficient liquidity (exceeding the project budget); inefficient use of property and incompetence of staff. Risks are ranked by degree of probability in coordination with possible damage, and a bar graph and a sign model are used to illustrate (Fig. 5). The bar chart helps to quickly understand the distribution of risks by increasing probability of occurrence and limit their list, and the sign simplifies the model without changing its essence and purpose, and increasing the color intensity makes it easy to identify a trend and remember priority risks.

Example 5. A client asset. According to P. Drucker, there is one legitimate justification for the purpose of the business - this is the creation of a satisfied client. Today, customer focus is the foundation of the mission of commercial organizations, and the effective management of a client's asset is becoming a key condition for profit. Potential partners of the project are aware that in the conditions of globalization in competitive markets, differences in quality, price and assortment of products are leveled out, the interests and expectations of customers, who increasingly make purchasing decisions based on non-price factors, become priority. There is increased interest in forecasting the frequency of purchases and the distribution of customers.

Different methods of visualizing a client's asset are possible - three-dimensional models (checks, shops and the number of purchases by the breadth of the basket and in the context of «traditional» and "non-traditional» purchases); models of groups of abnormal purchases (details of customers differing in consumer preferences); models of project results. Market segments can also be compared: a) a bar graph - a forecast of the dynamics of sales volume by years; b) a linear graph - a forecast of the dynamics of a client asset; c) pie chart structure of a client asset; d) the sign of Varzar - the annual amount of revenue from the sale of the same volume of goods on the average bill (Fig. 6).

A variety of graphic images retains active interest, provides constructive criticism, search and analysis of the problem from different points of view and interests, making the discussion of a new commercial idea comprehensive and complex. Existing design patterns help to choose customers by type of consumer behavior and active sales technologies (Ekhlakov Yu.P., 2018) [19], and visual analysis, influenced by the interests, perceptions and awareness of the user, initiates new questions and assessments, criticisms, and hypotheses (Ware $\mathrm{C}$ $., 2012)[20]$. 


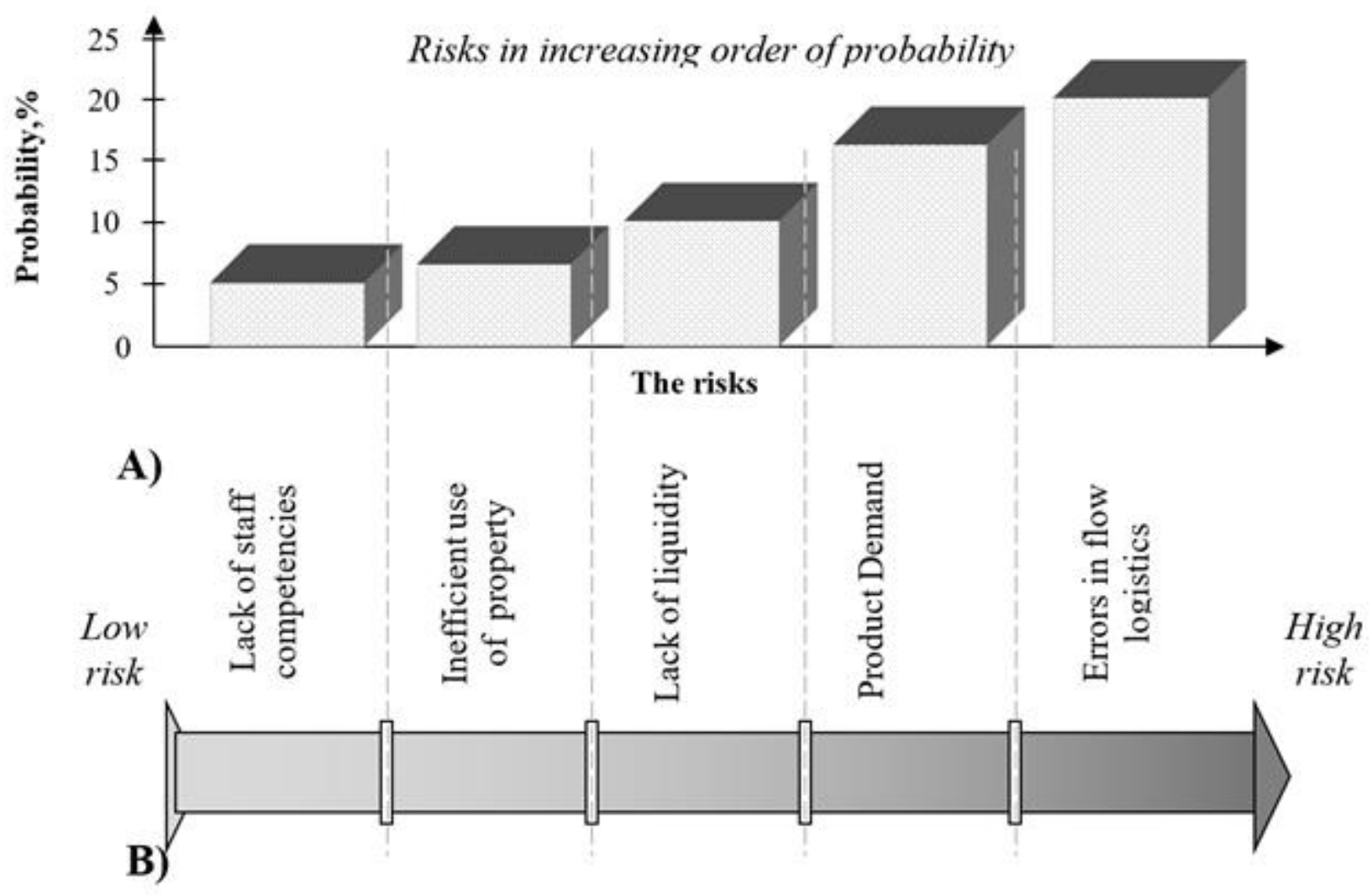

Fig. 5. Visualization of project risks: A - chart form, B - sign form
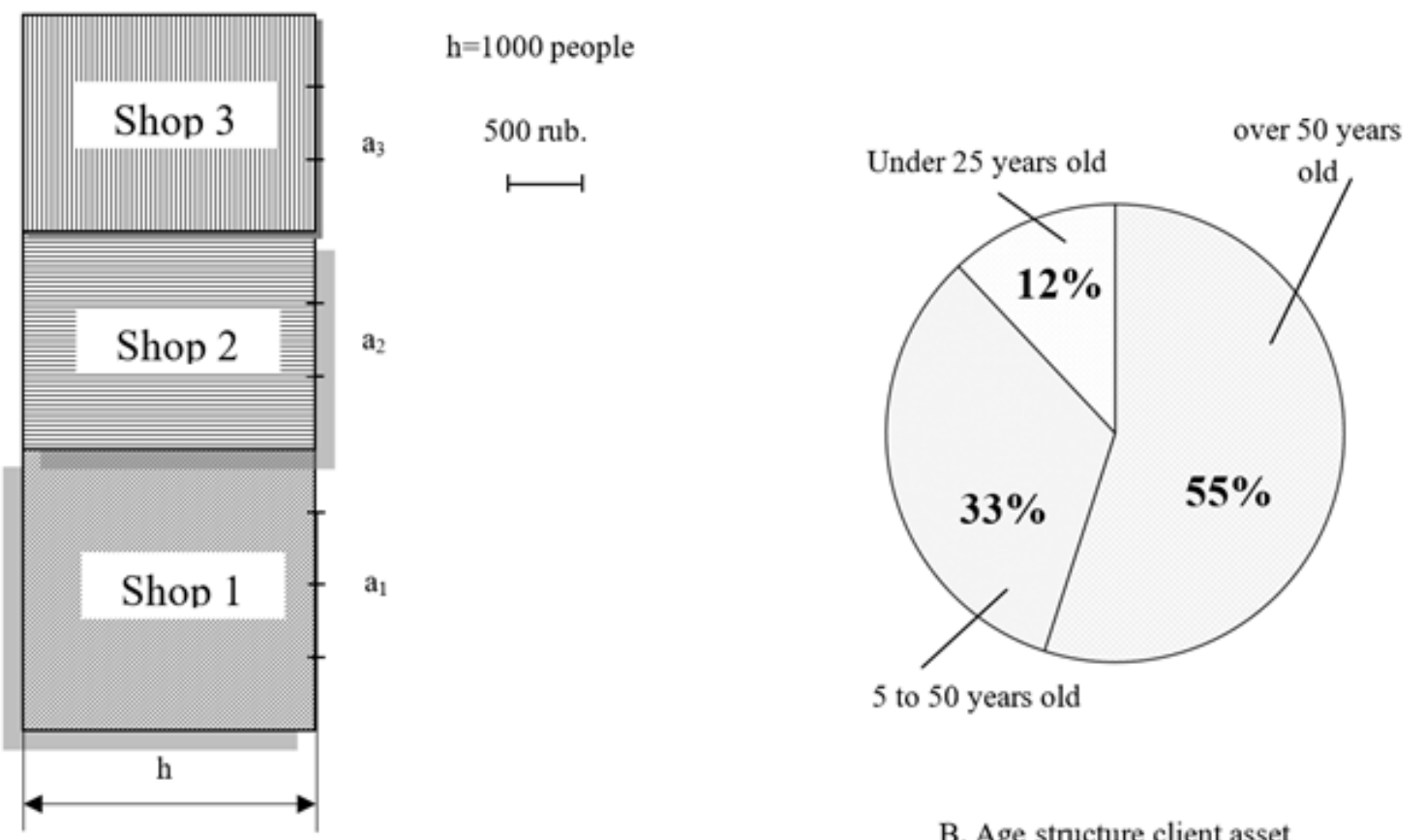

B. Age structure client asset

A. Daily revenue from 1000 people. customer asset by average bill (a) 


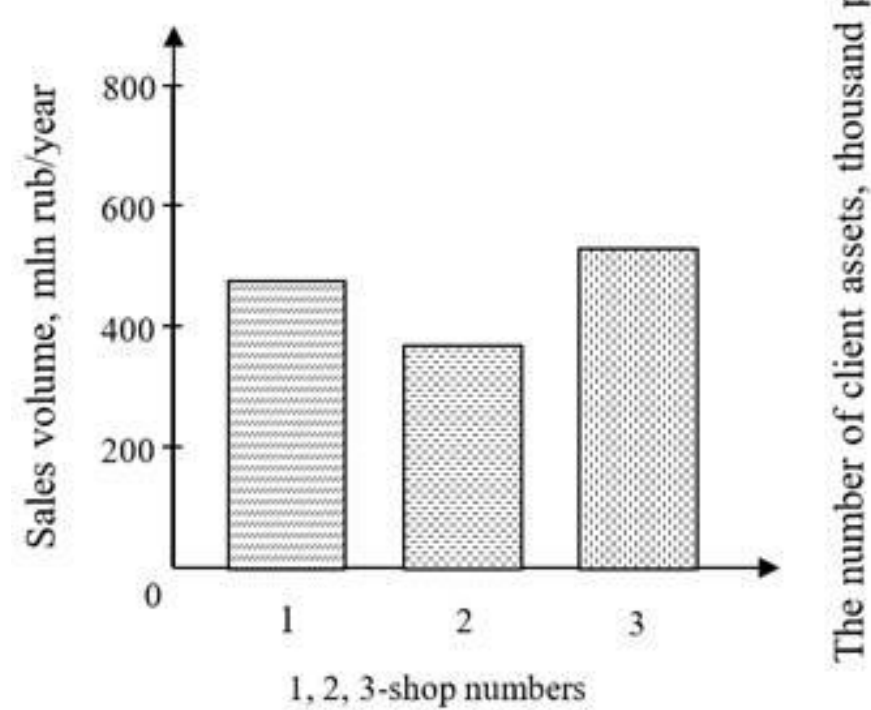

B. Annual sales

Bar chart

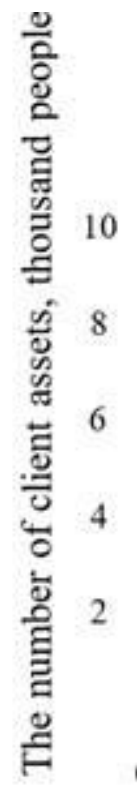

0

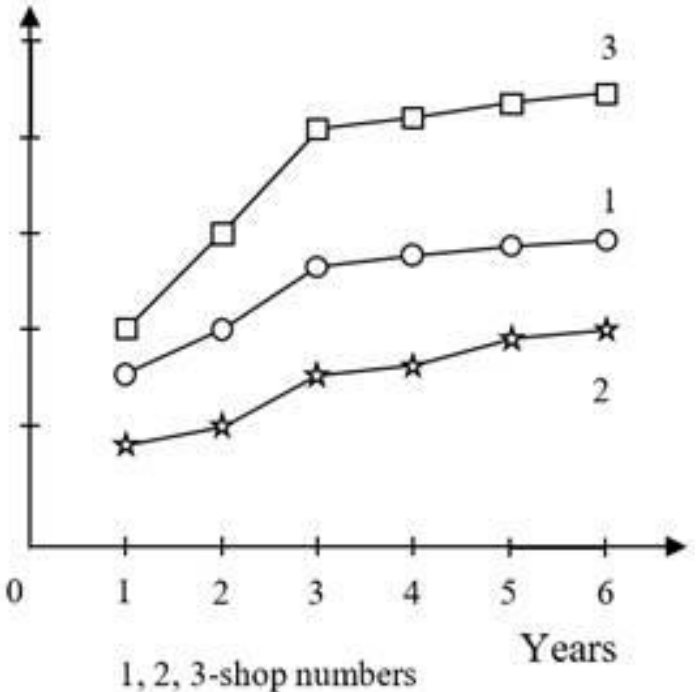

D. Client Asset Dynamics

Line graph

Fig. 6. Variants of visualization of information on client assets and sales

\section{Conclusion}

A competitive innovative economy increases the relevance of the creative component of business-planning, implemented, inter alia, by a set of visual cognitive operations and mechanisms for arguing the commercial feasibility and benefits of the proposed activity, despite the risk and limited resources. The project should be understandable to a wide range of people, therefore visual content helps to avoid technical details, gives realism, conciseness, persuasiveness, an accompanying emotional background and even a sensible element of advertising, and, most importantly, activates imaginative thinking and evokes associations that turn into a positive attitude towards innovation. The above examples show the feasibility of expanding graphical models to support a business plan.

\section{Literature}

1. Gavrilova T., Alsufyev A., Janson A. S. Modern notations of business models: visual trend /foresight, 2014, vol. 8, № 2, pp. 56-70. $-368 \mathrm{p}$.

2. Kozubovsky V. M. General psychology: cognitive processes. Minsk: Amalfeya, 2008

3. Bolter J.D. Examining and Changing the World of Media /Humanistic Perspectives in a Technological World. Ed. By Richard Utz, Valerie B. Johnson, etc. - Atlanta: School of Literature, Media and Communication, Georgia Institute of Technology, 2014, p. 37-40.

4. Zakharova A.A., Shklyar A.V. Visual representation of different types of data using dynamic sign structures /Scientific Visualization, 2016, V. 8, No. 4. P.28-37.

5. Madigan S., Rouse M. Picture memory and visual generation processes. The American Journal of Psychology, 1974, Vol. 87, № 1-2. P. 151-158.

6. Kuznetsov S. D. database Basics. M: INTUIT, 2005. $488 \mathrm{c.}$

7. Loginov G. O., Popov E. V. Matrix methods of strategic planning of the company /Management in Russia and abroad, 2004, № 2, Pp. 103-114.

8. A Guide to the Business Analysis Body of Knowledge $®$ (BABOK $®$ Guide). Version 3. Toronto: International Institute of Business Analysis, 2015. 
9. Langacker R. A course in cognitive grammar Manuskript; Preliminary draft. San Diego: UCSD, 2000. - 73 p.

10. Pirolli P., Card S.K. Information foraging in information access environments /Proceedings of CHI '95, ACM, 1995. P. 51-58.

11. Lychkina N. N. Synergetics and development processes in socio-economic systems: search for effective model structures /Business Informatics, 2016, № 1 (35), pp. 66-79.

12. Verbitsky A. A. Active learning in higher school: the contextual approach M.: Higher School, 1991. - 207 p.

13. Syrina T. A. Cognitive visualization: the essence of the concept and its role in language teaching / Bulletin of Tomsk state pedagogical University, 2017, № 7 (172), pp. 81-85.

14. Manko N. N. Cognitive visualization of didactic objects in the activation of educational activity /Proceedings of the Altai state University. Series: Pedagogy and psychology, 2009, № 2, p. 22-28.

15. Cuba N. Research Note: Sankey diagrams for visualizing land cover dynamics /Landscape and Urban Planning. 2015. No. 139. Pp. 163-167.

16. Laptev V. V., Orlov P. A., Dragunova O. V. Visualization of dynamic data structures using flowcharts in web Analytics /Scientific and technical sheets of SPbSPU: Informatics, telecommunications, management, 2017, vol. 10, № 4, p. 7-16.

17. Koffka K. Principles of Gestalt psychology. NY: Harcourt, 1963. 720 p.

18. Few S. Information Dashboard Design: The Effective Visual Communication of Data. O'Reilly Media, 2006. - 166 p.

19. Yehlakov Y.P., Malakhovskaya E.K. Patterns of designing the content of a communication message for promoting software products to the corporate market /Business Informatics, 2018, No. 1 (43). Pp. 50-60.

20. Ware C. Information Visualization. Third Edition (3rd Edition) Perception for Design (Interactive Technologies), Morgan Kaufmann, 2012. P. 536. 